\title{
THE MODEL TO ASSESS THE IMPLEMENTATION OF TECHNICAL CONDITIONS DEFINED IN ANNEX IV OF MARPOL CONVENTION 73/78: THE CASE OF THE BALTIC SEA PORT OF KLAIPEDA
}

\author{
Andrius Jarzemskis ${ }^{1}$, Ilona Jarzemskiene ${ }^{2}$ \\ Vilnius Gediminas Technical University \\ Faculty of Transport Engineering, Department of Logistics and Transport Management \\ Vilnius, Lithuania, Plytines 27, Vilnius \\ landrus.jarzemskis@vgtu.lt; ${ }^{2} I l o n a . j a r z e m s k i e n e @ v g t u . l t ~$
}

\begin{abstract}
Baltic Marine Environment Protection Commission members seeking to implement MARPOL 73/78 Annex IV amendments which recognize the Baltic Sea as special are, in which discharge of uncommitted sewage from passenger ships is forbidden, must ensure that ports are equipped with adequate reception facilities. To ensure implementation of amendments of Annex IV in port of Klaipeda, the analysis framework model was defined by authors. The model evaluates the readiness of the port to changes brought by the amendments of MARPOL Annex IV. The scientific problem comes with perception of adequacy. Resolution MEPC.200(62) amending MARPOL 73/78 Annex IV states, that port reception facilities must be adequate to the needs of passenger ships using them without causing undue delay. Concept of adequacy is not defined, therefore other guidelines explaining adequacy were used: EU directive 2000/59/EC and IMO resolution MEPC.83(44) Guidelines for ensuring adequacy of port reception facilities. Based on these sources, criteria that must be met to ensure adequacy were identified and tested in article: 1) reception facilities meet needs of ships normally using them;2) discharge of sewage does to cause undue delay; 3) reception facilities does not provide disincentive to use them; 4) facilities are accessible; 5) facilities contribute to the improvement of the marine environment.
\end{abstract}

Keywords: MARPOL, sewage reception, port, ferries, environment policy

\section{Introduction}

The environment indicators is becoming more actual in port competition as mentioned by Zondag et al. (2010), Moon and Woo (2014), Luo and Yip (2013). Both port operators and shipping lines operators introducing their green shipping practices across the world (Venus et al., 2014; Chin-Shan et al., 2014). In parallel to competition the new set of requirements is shaped by international agreements as highlighted by Panasiuk and Lebedevas (2014), Julian (2000), Everett and Pettitt (2006).

Ports are dealing with pollutions that is originated by ship operators as mentioned by Homsombat et al. (2013), Klopott (2013), Liu and Maes.

Baltic Sea is one of the smallest and one of the most isolated seas on the global scale. It is connected with North Sea and The Atlantic Ocean by two shallow and narrow straits, therefore renewal of seawater is slow and it takes 25-35 for the Baltic Sea to completely renew itself. Discharge of sewage into the seawater has negative impact on ecosystem; phosphorus and nitrogen compounds, other types of food waste, bacteria, viruses, other pathogens and detergents, heavy metals pollute marine environment. Sewage mixes with seawater and contributes to increase of levels of nutrition (eutrophication) for sea animals and vegetation. Eutrophication is the process by which a body of water acquires a high concentration of nutrients, especially phosphates and nitrates. These typically promote excessive growth of algae. As the algae die and decompose, high levels of organic matter and the decomposing organisms deplete the water of available oxygen, causing the death of other organisms, such as fish.

The Baltic Sea is recognised as special area under International Convention for the Prevention of Pollution from Ships (MARPOL 73/78) Annex I Prevention of pollution by oil, Annex II Control of pollution by noxious liquid substances, Annex IV Prevention of pollution by sewage from ships and Annex V Prevention of pollution by garbage from ships. The Baltic Sea is the only special area under Annex IV.

Special areas as defined by MARPOL 73/78 are sea areas in which, for technical reasons relating to their oceanographic and ecological condition and to their sea traffic, the adoption of special mandatory methods for the prevention of sea pollution is required. Annex IV was adopted in 2003. It contains a set of regulations regarding the discharge of sewage into the sea from ships, including regulations regarding 
the ships' equipment and systems for the control of sewage discharge, the provision of facilities at ports and terminals for the reception of sewage, and requirements for survey and certification. It also includes a model International Sewage Pollution Prevention Certificate to be issued by national shipping administrations to ships under their jurisdiction. Discharge of untreated sewage to the Baltic Sea from passenger ships will be prohibited when amendments to Annex IV come into effect.

The new special area requirements, which enter into force on 1 January 2013, will only take effect upon receipt of sufficient notifications on the existence of adequate reception facilities from Parties to MARPOL Annex IV whose coastlines border the Baltic Sea (regulation 13.2 of the revised MARPOL Annex IV, which was adopted by resolution MEPC.200(62) and enter into force on 1 January 2013).

The scientific problem comes with perception of port adequacy. In order to provide such notification the model of evaluation of adequacy is prepared and tested in the article by case of Klaipeda State Seaport. Baltic Marine Environment Protection Commission in HELCOM recommendation 11/10 Guidelines for capacity calculation of sewage system on board passenger ships (1990) and HELCOM overview on port reception facilities for sewage in the Baltic Sea area and related trends in passenger traffic (2013) both gives only the directions on capacity calculation.

\section{Definition of sewage according to MARPOL $73 / 78$ Annex IV and sewage handling options}

Definition of sewage from ships is provided in MARPOL 73/78 Annex IV:

- drainage and other wastes from any form of toilets and urinals;

- drainage from medical premises (dispensary, sick bay, etc.) via wash basins, wash tubs and scuppers located in such premises;

- drainage from spaces containing living animals;

- other waste waters when mixed with the drainages defined above.

Republic of Lithuania adopted MARPOL 73/78 convention in year 1991. MARPOL 73/78 Annex IV prevents pollution by sewage from ships. Annex IV was adopted by Republic of Lithuania in year 2003. In year 2011, amendments to Annex IV were adopted, declaring Baltic Sea as a Special Area in Annex IV and providing more stringent requirements for discharge of sewage from passenger ships. Relevant provisions and amendments to provisions are provided in Table 1.

Table 1. Relevant provisions of MARPOL 73/78 Annex IV

\begin{tabular}{|l|l|}
\hline Document & Provision \\
\hline $\begin{array}{l}\text { Relevant provisions } \\
\text { of MARPOL 73/78 } \\
\text { Annex IV }\end{array}$ & $\begin{array}{l}\text { - The Government of each Party to the Convention undertakes to ensure the provision of facilities at } \\
\text { ports and terminals for the reception of sewage, without causing undue delay to ships, adequate to meet } \\
\text { the needs of the ships using them; } \\
\text { - Standard dimensions of flanges for discharge connections. }\end{array}$ \\
\hline $\begin{array}{l}\text { Relevant amended } \\
\text { provisions of }\end{array}$ & $\begin{array}{l}\text { - Baltic sea is recognized as Special are as defined in regulation 1.11.2 of Annex I; } \\
\text { MARPOL 73/78 }\end{array}$ \\
Annex IV & $\begin{array}{l}\text { a) for new passenger ships on, or after 1 January 2016, subject to regulation 12bis, subparagraph 2; and } \\
\text { b) for existing passenger ships on, or after 1 January 2018, subject to regulation 12bis, subparagraph 2. }\end{array}$ \\
& $\begin{array}{l}\text { Each Party, the coastline of which borders a special area, undertakes to ensure that: } \\
\text { o facilities for the reception of sewage are provided in ports and terminals which are in a special }\end{array}$ \\
& o the facilities are adequate to meet the needs of those passenger ships; \\
& o the facilities are operated so as not to cause undue delay to those passenger ships.
\end{tabular}

According to amendments of MARPOL 73/78 Annex IV, following sewage handling options are provided, depending on type of ship:

- other than passenger ships: the ship is discharging comminuted and disinfected sewage using a system approved by the Administration in accordance with regulation 9.1.2 of this Annex at a distance of more than 3 nautical miles from the nearest land, or sewage which is not comminuted or

- disinfected at a distance of more than 12 nautical miles from the nearest land;

- passenger ships: sewage may be discharged if a passenger ship is equipped with a sewage treatment plant which shall be of a type approved by the Administration, taking into account the standards and test methods developed by the Organization;

- passenger ships: sewage may be discharge in port reception facilities if ship is equipped with a holding tank of the capacity to the satisfaction of the Administration for the retention of all sewage, having regard to the operation of the ship, the number of persons on board and other 
relevant factors. The holding tank shall be constructed to the satisfaction of the Administration and shall have a means to indicate visually the amount of its contents.

There are three types of Port reception facilities:

1. Fixed facilities installed in berths where passenger ships anchor;

2. Floating reception facilities, usually tankers;

3. Mobile reception facilities - trucks.

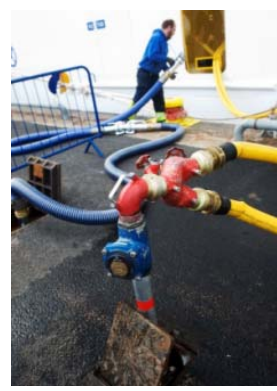

a)

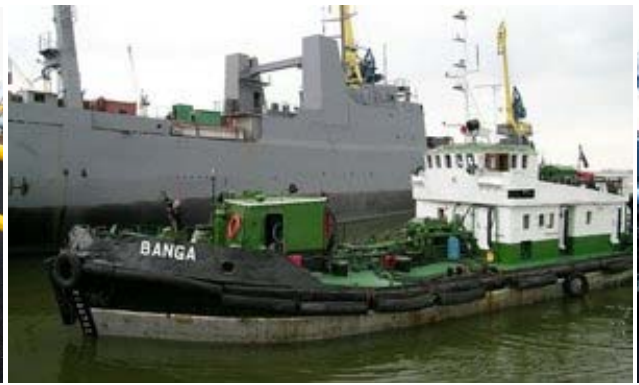

b)

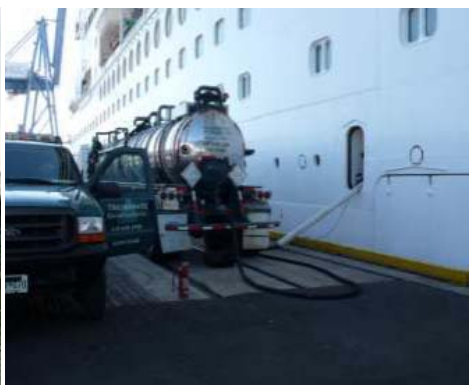

c)

Figure 1. a) Stationary port reception facility, b) Floating port reception facility, c) Mobile port reception facility

Stationary port reception facilities. Stationary port reception facilities accept sewage only in specific berths; therefore this type of PRF should be installed in all berths serving passengers ships to ensure that sewage is accepted from any ship willing to discharge. Investments in fixed PRF is relatively high compared to other options, however this type of facility is the most durable: Port of Helsinki renovated its fixed PRF after 25 years of use as mentioned in Demand study port infrastructure (2013). Fixed PRF usually has greater pumping capacities $\left(100-200 \mathrm{~m}^{3} / \mathrm{h}\right)$ compared to other options. Fixed PRFs are usually installed in berths which serve ships with potentially large volumes of sewage - e.g. larger cruise ships may discharge $800-1200 \mathrm{~m}^{3}$ sewage per port call - or in the berths where ferries staying for short periods of time anchor. Fixed PRF are not economically feasible in those ports where discharged volumes of sewage are relatively small (up to $300 \mathrm{~m}^{3}$ per port call) or discharges are not frequent occurrence.

Floating port receptions facilities - Tankers. Tankers are able accepted sewage from ships anchored at in any berth (if technically possible). When requested, tankers accept sewage directly from ship anchoring next to it. When not accepting sewage, tankers are used for other services in the port, e.g. to accept other types of waste or deliver fuel. Tankers have limited capacities depending on size of particular tanker. Larger tankers are able to accept volumes of $1000 \mathrm{~m}^{3}$ and more, smaller tankers usually accept up to $300 \mathrm{~m}^{3}$ of sewage. In cases when large vessels are discharging sewage, tankers may be not sufficient to accept all sewage.

Table 2. Pros and cons for ship operator of each type of PRF

\begin{tabular}{|l|l|}
\hline Facilities & Pros and cons for ship operators \\
\hline Fixed reception facilities & $\begin{array}{l}\text { - Pros: the safest way to discharge sewage (minimized risks of leakage and odour), chances of } \\
\text { accidents are very slim as no other vessels or vehicles are involved. } \\
\text { Compared to other PRFs, fixed PRF have largest sewage reception capacities (in the most of cases } \\
\text { unlimited volumes) and the largest pumping capacities. Fixed PRF are usually connected to sewage } \\
\text { system of closest city, accepted sewage is treated in municipal sewage treatment plants. } \\
\text { Cons: in some cases, depending on construction of specific berth, hoses which are used to connect } \\
\text { ship and PRF may be in the way of other vehicles serving passenger ship or cause discomfort for } \\
\text { passengers. } \\
\text { This type of PRF is expensive to install, in some cases technically impossible if possibilities to } \\
\text { connect PRF and nearest sewage system are limited. Also, fixed PRF are only able to accept sewage } \\
\text { in the berths where they are installed. }\end{array}$ \\
\hline Tankers & $\begin{array}{l}\text { Pros: sewage may be accepted at any berth. } \\
\text { Cons: tankers anchor on the other side of the ship they are serving and usually are not visible for } \\
\text { passengers; however risk of accidents or damage to ship exterior might happen. Also, unpleasant } \\
\text { odours might have negative impact on passengers. }\end{array}$ \\
\hline Trucks & $\begin{array}{l}\text { Pros: sewage may be accepted in all berths where road access for vehicles is available. This type of } \\
\text { PRF is also relatively cheap compared to other options. } \\
\text { Cons: limited sewage volume capacities and pumping capacities; higher risk of leakage and } \\
\text { unpleasant odour, due to multiple times hoses are connected and disconnected. Parked trucks } \\
\text { providing service are considered to be unpleasant experience for ship passengers. }\end{array}$ \\
\hline
\end{tabular}


Mobile port receptions facilities - Trucks. Trucks are the smallest PRF, usually able to accept 8$12 \mathrm{~m} 3$ of sewage. Some tankers are larger, however normally capacities do not exceed $24 \mathrm{~m} 3$. Trucks are usually used to accept sewage from other ships than passenger ships or to accept small volumes of sewage when other options are unavailable. Trucks are more common in ports which do not serve cruise ships. Trucks have very limited capacities to accept large volumes of sewage. Also, trucks need safe access to ships; connected truck may become an obstacle for other operations with ship. Table 2 provides overview of pros and cons for ship operator of each type of PRF.

Passenger ships operators and port operators have very different views on what port reception facilities should be: ship operators require PRF both to be technically adequate and to be acceptable to their passengers (odour, view, getting in the way unboarding ship), while port operators are focused on meeting technical requirements.

\section{Overview of sewage reception facilities in Baltic Sea ports}

Larger passenger ports in the Baltic Sea, that serve passengers on daily basis and attract at least 500 th. passengers per year, usually install fixed sewage reception facilities. In smaller port, sewage is accepted using tankers or trucks (e.g. in port of Riga, in port of Helsingborg). This chapter overviews sewage reception facilities in other passenger serving ports in The Baltic Sea .

Seaports in the Baltic Sea usually serve more passengers from ferries than cruise ship passengers; however ports still have to accept sewage from cruise ships and port reception facilities must be adequate to serve cruise ships, which normally carry more passengers and trips are longer compared to ferries. Ports that seek to maintain and increase number of visiting cruise ship, usually install fixed reception facilities that meet needs of cruise ships the best. Demand study port infrastructure (2013) gives such figures:

Table 3. Overview of SRF in The Baltic sea ports serving cruise ships

\begin{tabular}{|l|l|l|}
\hline Port name & $\begin{array}{l}\text { Total number of passengers (out of which number } \\
\text { of cruise ship passengers), in thousands }\end{array}$ & $\begin{array}{l}\text { Type of SRF } \\
\text { (F - fixed, } \mathbf{~} \text { - tankers, } \mathbf{T r} \text { - trucks) }\end{array}$ \\
\hline Copenhagen & $1722(840)$ & $\mathrm{F}, \mathrm{T}$ \\
\hline Tallinn & $8800(440)$ & $\mathrm{F}, \mathrm{T}, \mathrm{Tr}$ \\
\hline Helsinki & $10600(365)$ & $\mathrm{F}$ \\
\hline Kiel & $1568(348)$ & $\mathrm{F}$ \\
\hline Rostock & $2343(300)$ & $\mathrm{F}, \mathrm{Tr}$ \\
\hline Riga & $361(83)$ & $\mathrm{Tr}$ \\
\hline Gdynia & $607(82)$ & $\mathrm{F}, \mathrm{Tr}$ \\
\hline Gothenburg & $1591(75)$ & $\mathrm{F}, \mathrm{Tr}$ \\
\hline Klaipeda & $340(26)$ & $\mathrm{T}, \mathrm{Tr}$ \\
\hline
\end{tabular}

Port of Helsinki, Finland SRF overview. In 2012, Port of Helsinki served 10,6 million passengers, out of which 365 th. were from cruise ships. The most of the passenger traffic comes from scheduled ferries. Berths, where ferries are served, are equipped with fixed sewage reception facilities. Waster waters are pumped from vessels via hoses in to the Port of Helsinki sewers and from there in to the general sewage system of the city. The receiving capacity of the reception facilities varies approximately from $60-120 \mathrm{~m}^{3} / \mathrm{hr}$ depending on the solid content of the waste water. Vessels can be offered the opportunity to discharge waste water through two hoses, allowing the vessel to discharge twice as much waste water. Reception capacities are limited by ship pumping capacities. Non-special fee is charged for reception of any amount of black or grey waste water.

Port of Tallin, Estonia SRF overview. In 2012 port served 8,8 million passengers, out of which 440 th. were from cruise ships. The most of the passenger traffic comes from scheduled ferries. Depending on specific berth, different types of SRF are installed: berths 1 and 3 are equipped with fixed $\mathrm{SRF}$ with up to $30 \mathrm{~m}^{3} / \mathrm{h}$ pumping capacity, other 19 berths are served with tankers (up to $150-300 \mathrm{~m}^{3}$ ) and trucks (up to $7-17 \mathrm{~m}^{3}$ ). Non-special fee is charged for reception of sewage. Sewage volumes exceeding 7 $\mathrm{m}^{3}$ are subject to extra payment.

Port of Trelleborg, Sweden SRF overview. The port serves ferry lines, in 20121500 th. passengers were served. Berths are equipped with sewage pumping stations. The pump can either be 
placed above or underground. Each pump station has a capacity of pumping $80 \mathrm{~m}^{3} / \mathrm{h}$ and also has a depository of $8 \mathrm{~m}^{3}$, which the Port of Trelleborg has dimensioned in mutual agreement with the shipping companies serving in the port.

Port of Stockholm, Sweden SRF overview. In 2012 port served 12 million passengers, out of which 463 th. were from cruise ships. Port is equipped with fixed sewage reception facilities in all berths. The sewage is pumped directly to communal sewage system. Pumping capacities depend on specific berth. In Frihamen port the reception facilities are located every 60 meters, implying that the distance to the vessel is never more than 30 meters. Flexible hoses are used to connect ships to the SRF. In cases where vessels cannot use the available reception facilities or on locations in the port where the fixed installations are missing, such as the container terminal, waste water is collected by truck. Non-special fee is charged for reception of any amount of black or grey waste water.

\section{Forecast of change in volumes of sewage received in port of Klaipeda due to amendments to IV Annex of MARPOL 73/78 convention}

\subsection{General statistics}

The Baltic Sea is recognised as special area under MARPOL 73/78 Annex IV, prohibiting discharge of untreated sewage from passenger ships. These amendments will have direct impact on passenger ships using port of Klaipeda and are likely to contribute to growth of sewage volumes accepted in the port. Amendments will come into force once ports in the special are report adequacy of their PRF, therefore PRF in port of Klaipeda need to be assessed to report adequacy. For the assessment, likely increase of volumes from ships normally using port of Klaipeda, will be forecasted and compared to sewage reception capacities.

Following aspects were considered to justify assumption forecast:

- geographical location of port of Klaipeda;

- $\quad$ profile of passenger ships normally using the port;

- $\quad$ expected growth of ship traffic;

- $\quad$ likely volumes of sewage per passenger ship normally using the port.

Port of Klaipeda serves both freight and passenger ships. During the period of 2010-2013, 14 per cent of ships served by the port were passenger ships. Share of passenger ships from total number of ship calls increased by approximately 4 per cent points compared to period of 2005-2009.

During the period of 2005-2013, total number of port calls in port of Klaipeda shrunk by 16 per cent: number of other than passenger ships shrunk by 1500 per year, however during the period of 20112013 number of passenger ships remained stable (more than 950 ships per year)

The most of the passenger ships visiting port of Klaipeda were Ro-Pax ships (86 per cent), other 4 per cent were cruise ships. During the period of 2005-2013, number of passenger ships visiting port of Klaipeda increased by 11 per cent. During the period of 2010-2013, port of Klaipeda was visited by 900 of Ro-Pax ships and over 40 of cruise ships. In 2014, port of Klaipeda was visited by 62 cruise ships.

Number of passengers in port of Klaipeda increased by 61 per cent during the period of 20052013, growth came from of the passengers transported by Ro-Pax ships. In 2013, Ro-Pax ships transported 280 th. passengers. There is no clear growth trend in passenger numbers from cruise ships, as number of cruise ship calls per year is different. Figure 9 provides combined number of passengers that arrived and departed, further evaluation will only consider number of arriving passengers. In 2013,33 th. passengers arrived in cruise ships, in 2014 number of passengers increased to 45 th., number of cruise ships increased by 22 ships.

Passenger ships using port of Klaipeda anchor in Klaipeda ferry terminal (International Ferry Terminal), Central Klaipeda terminal and in Cruise and naval vessel quay. Klaipeda ferry terminal (International Ferry Terminal) currently serves Ro-Pax ferries, serving two routes. Terminal is operated by company DFDS Seaways. Up to three ferries may be anchored at the same time. Cruise and naval vessel quay only serves cruise ships, up to two ships may be anchored at the same time. Klaipeda ferry terminal (International Ferry Terminal) may serve up to three vessels at the same time. Port of Klaipeda usually serves ships sailing within the Baltic Sea: Ro-Pax ferries to Sweden and Germany, and cruise ships taking cruise around Baltic Sea ports. Normally, passenger ships arriving to port of Klaipeda will have their trip shorter than 24 hours. 


\subsection{Ro-Pax vessels in port of Klaipeda}

DFDS Seaways is the only company operating regular ferry routes in port of Klaipeda. Company serves routes using Ro-Pax ships carrying vehicles and passengers. All Ro-Pax ferries served in port of Klaipeda were operated by DFDS Seaways. Average number of ferry passengers per year was 282 th., each ferry carries average of 305 passengers (see Fig. 2). Approximate average number of passengers per ferry is 305, however capacities of all ferries used by DFDS Seaways are larger and carry up to 600 passengers. DFDS Seaways operates two regular routes Klaipeda-Kiel (Germany) and KlaipedaKarlshamn (Sweden). Klaipeda-Kiel has six trips per week; Klaipeda-Karlshamn has seven trips a week (Table 4).

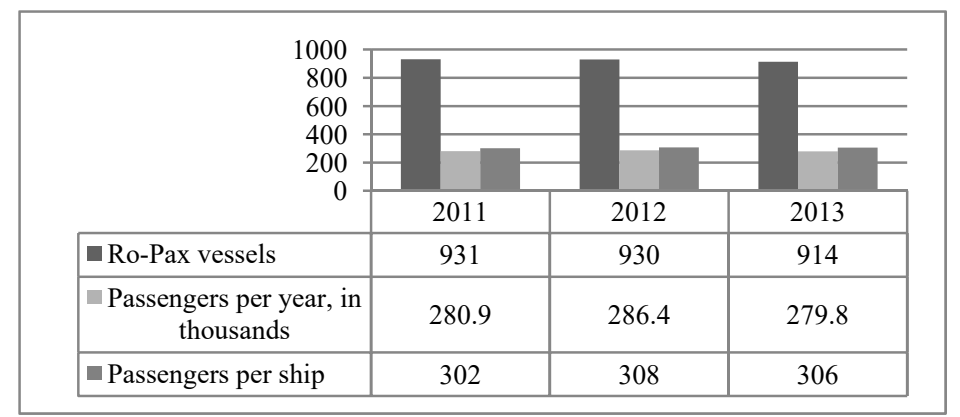

Figure 2. Ro-Pax ferries in port of Klaipeda, approximate averages

Table 4. Ferries served in port of Klaipeda operated by DFDS Seaways

\begin{tabular}{|l|l|l|l|}
\hline Routes & Frequency (times per week) & Ships & $\begin{array}{l}\text { Maximum number } \\
\text { of passengers }\end{array}$ \\
\hline Klaipeda - Kiel & 6 , both directions & Regina Seaways & 532 \\
\hline Klaipeda - Kiel & 6 , both directions & Victori Seaways & 515 \\
\hline Klaipeda - Karslshamn & 7 , both directions & Athena Seaways & 600 \\
\hline Klaipeda - Karslshamn & 7 , both directions & Optima Seaways & 323 \\
\hline
\end{tabular}

Route Klaipeda-Kiel is operated six times a week, on trip lasts 20 hours. Route is served with "Regina Seaways" and "Victoria Seaways". Route Klaipeda-Karlshamn is served daily, trip duration is 13 hours. Route is served with "Athena Seaways" and "Optima Seaways" (Fig. 3).

Ferries operate on fixed schedule. Figure 5 depicts periods when ferries are anchored in the port of Klaipeda according to schedule of 2014. Ferries serving route Klaipeda-Kiel are depicted in blue (A and B mark different ferries operating route), red colour depicts ferries operating Klaipeda-Karlshamn. Normally, up to two Ro-Pax ferries are anchored at the port at the same time for at least 5 hours.

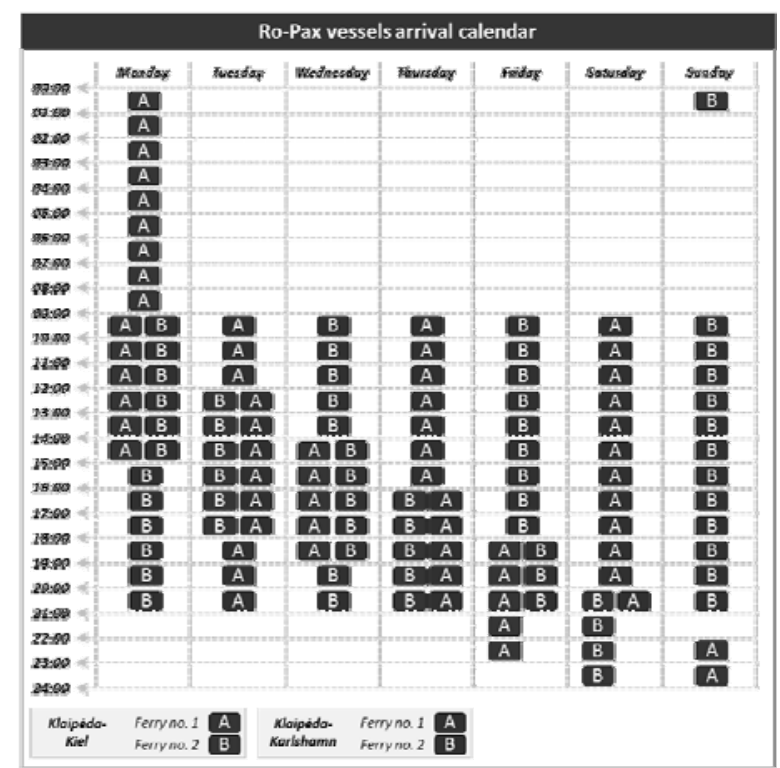

Figure 3. Ro-Pax ferries in port of Klaipeda 


\subsection{Cruise ships in port of Klaipeda}

Cruise ships are served at Central Klaipeda terminal and at Cruise and naval vessel quay. On average, 45 cruise ships visit port of Klaipeda every year carrying average of 31,5 th. passengers. Average approximate number of passengers per ship is 692. Cruise ships visit port of Klaipeda May to October (Fig. 5) and 72 per cent of ships arrive on summer months.

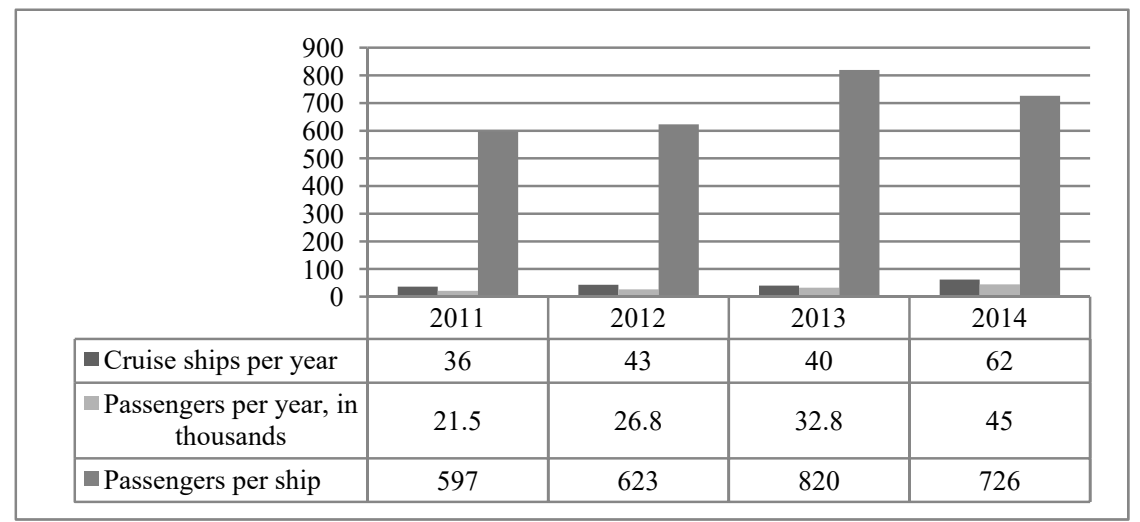

Figure 4. Cruise ships in port of Klaipeda, approximate averages

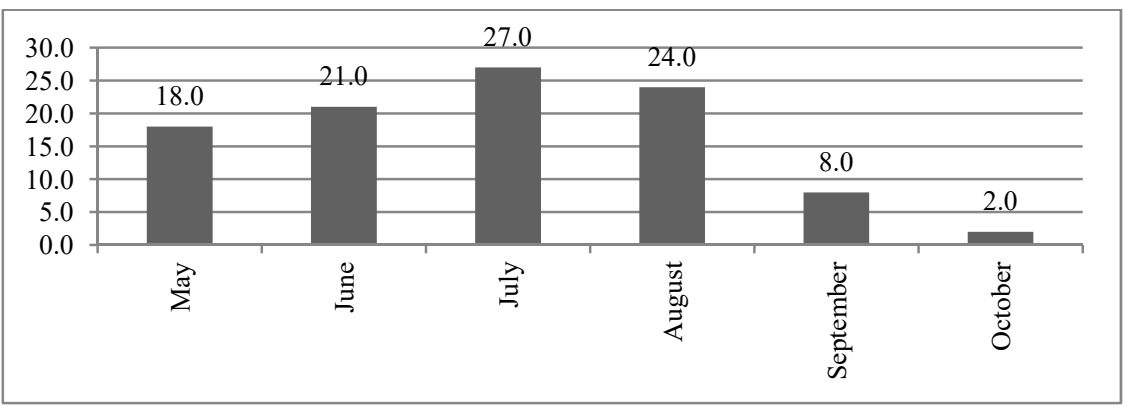

Figure 5. Distribution of cruise ships in port of Klaipeda, 2014 (in \%)

Schedules from cruise season 2014 were used for further analysis. Findings of the analysis (Fig. 6) revealed that:

- All the cruise ships visiting port of Klaipeda were anchored between hours 13 and 15;

- More than 90 per cent of ships were anchored in port of Klaipeda between hours 12 and 16;

- More than 80 per cent of ships were anchored in port of Klaipeda between hours 10 and 17;

- More than 70 per cent of ships were anchored in port of Klaipeda between hours 9 and 18 .

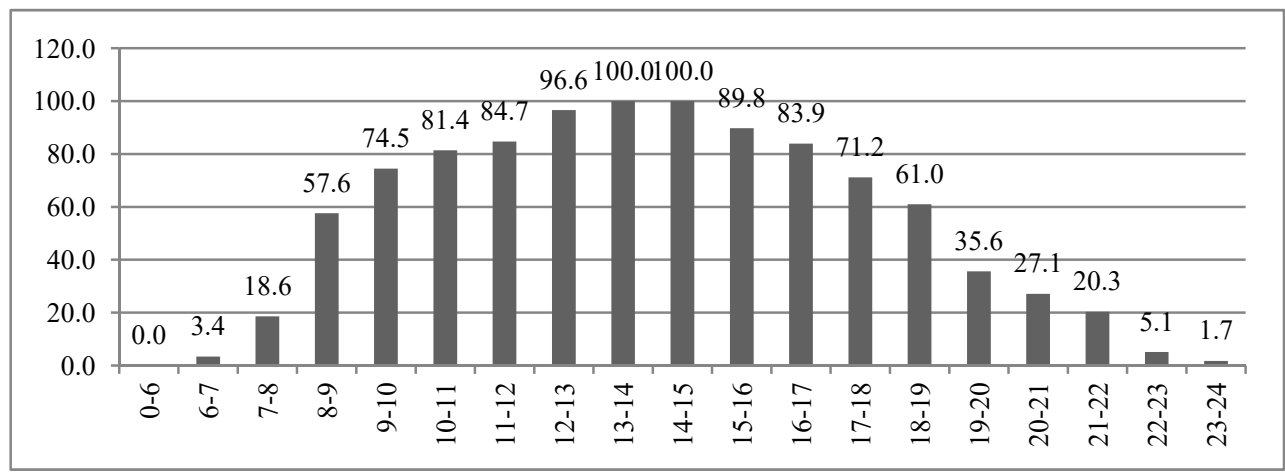

Figure 6. Distribution of cruise ships by the hours they were staying at the port of Klaipeda, 2014 (in \%) 
Analysis of cruise ships staying in port of Klaipeda (Fig. 7) revealed following findings:

- 98 per cent of ships staying in port of Klaipeda spend there at least 6 hours;

- More than 90 per cent of ships staying in port of Klaipeda stay at the port for at least 7 hours;

- 75 per cent of cruise ships spend at least 8 hours in port of Klaipeda.

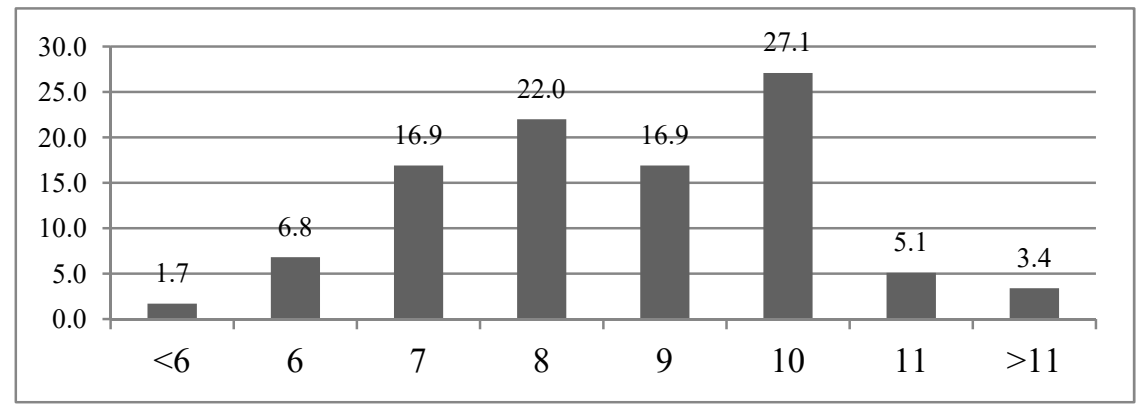

Figure 7. Distribution of cruise ships by the time spent in port of Klaipeda, 2014 (in \%)

As displayed in Figure 8, the most of the cruise ships arrive on Tuesday (21 per cent) and Thursdays (19,4\%), least ships arrive on Monday and Sunday (accordingly 9,7 per cent) and on Saturdays $(11,3 \%)$.

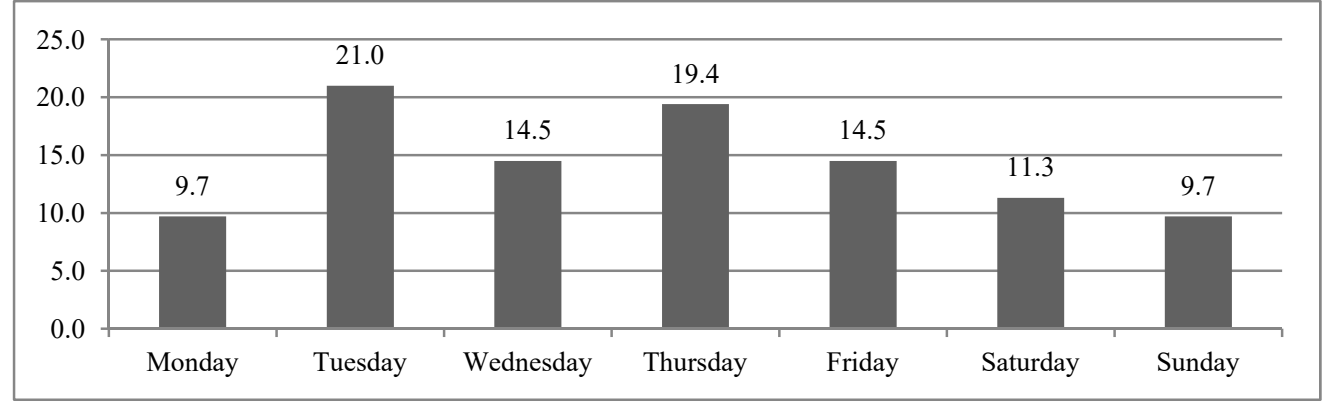

Figure 8. Distribution of cruise ships by day of arrival, 2014 (in \%)

\subsection{The most likely scenario of passenger ship traffic in port of Klaipeda}

Analysis of ships normally using port of Klaipeda revealed that the most likely scenario of maximum load is 5 passenger ships staying at the port at the same time (between hours 9 and 18): 2 RoPax ferries and 3 cruise ships (Fig. 9). Usually up to two Ro-Pax ships stay at the port anchored for at least 5 hours. Normally, up to 3 cruise ships stay at the port at the same time, spending at least 7 hours, between hours 12 and 16 .

\subsection{Current and forecasted volumes of sewage in port of Klaipeda}

Data from Klaipeda state seaport authority for year 2005-2009 and 2011-2013 reveals that port of Klaipeda accepts approximately $300 \mathrm{~m} 3$ of sewage every year. In 2014, according to data from company responsible for sewage handling UAB "Baltijos bunkeriavimo agentūra", sewage was accepted this, total volume accepted being $362 \mathrm{~m} 3$. Sewage was accepted from cruise ships. Ferries operating routes from port of Klaipeda are equipped with sufficient on-board sewage treatment facilities and do not use sewage reception facilities in port of Klaipeda.

Current data on accepted sewage volumes does not provide sufficient base for justified assumptions for adequacy assessment after amendments to Annex IV come into force, therefore likely maximum volumes of sewage to be discharged in port of Klaipeda will be calculated using HELCOM guidelines and statistic data from other ports in the Baltic Sea.

This scenario will be used to justify assumptions and assess adequacy of sewage reception facilities in port of Klaipeda. 


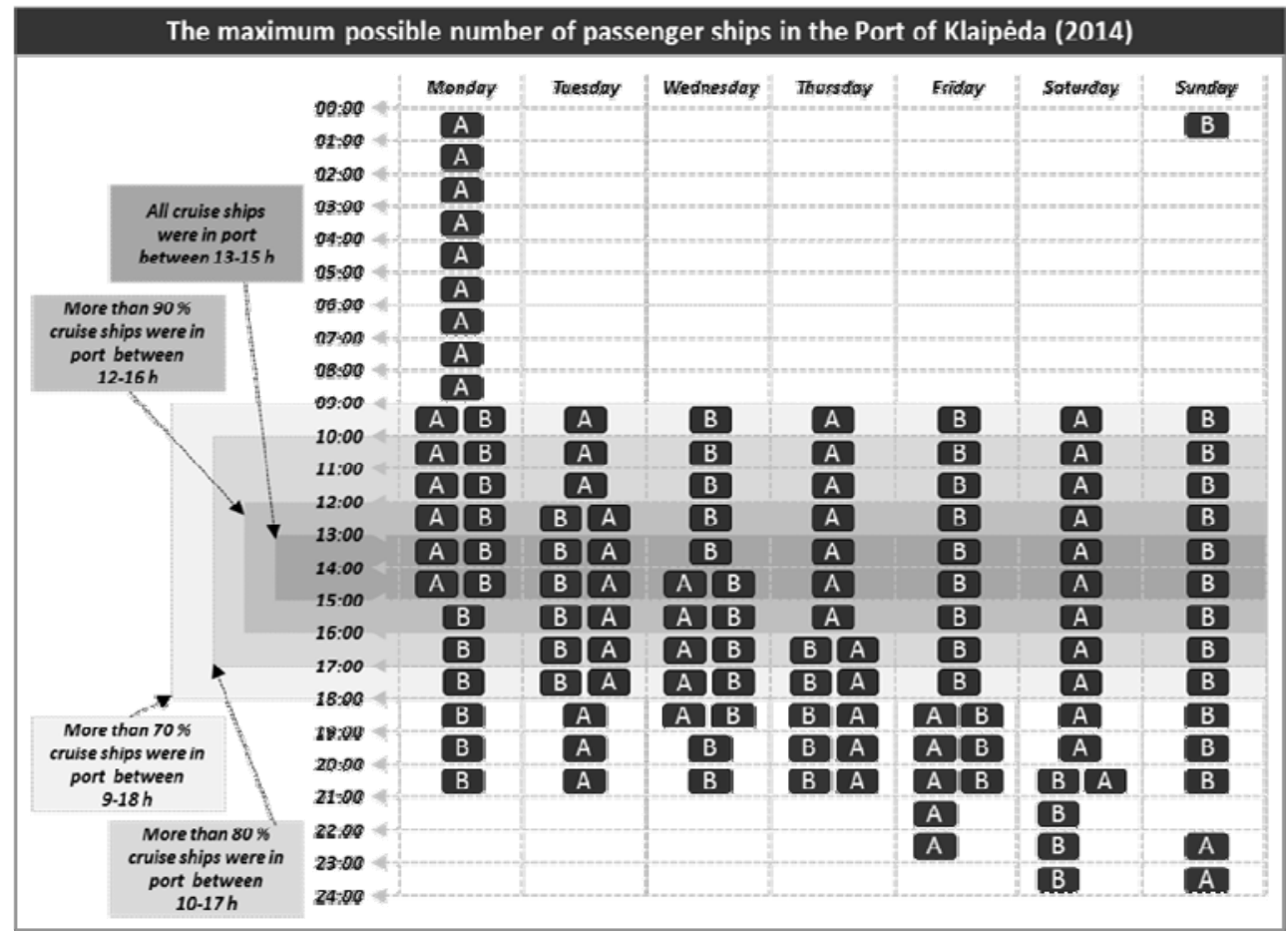

Figure 9. The most likely realistic scenario of maximum load in port of Klaipeda

MEPC.200(62) resolution amends Annex IV and declares the Baltic sea special area, where discharge of untreated sewage from passenger ships is prohibited. Following amendments are the most relevant in context of the study as having impact on volumes of sewage accepted in port of Klaipeda:

- Passenger ships must be equipped with approved on-board sewage treatment facilities to discharge sewage into sea;

- or sufficient storage tank to contain sewage during the trip.

The discharge of sewage from a passenger ship within a special area shall be prohibited:

- for new passenger ships on, or after 1 January 2016;

- for existing passenger ships on, or after 1 January 2018.

These amendments will impact passenger ships operating in the Baltic Sea which are not equipped with sufficient sewage treatment facilities or not equipped with sewage treatment facilities at all; these ships will have to discharge sewage into port reception facilities, possibly increasing volumes of sewage accepted in port of Klaipeda. Analysis of cruise ships to visit port of Klaipeda in 2015 revealed that 90 per cent of ships were built during the period of 1970-2010, therefore it is unlikely that large number of new ships will visit port of Klaipeda in 2016, therefore volumes of sewage are likely to increase after amendments come into force for all passenger ships is 2018. Due to this circumstance, adequacy of reception facilities in port of Klaipeda will be assessed modelling scenarios in 2018.

Data is insufficient to provide justified assumptions whether passenger ships operating in The Baltic sea will improve their sewage treatments equipment, therefore scenario implying that all the ships visiting port of Klaipeda will discharge sewage will be assessed to evaluate adequacy. Theoretic maximum likely traffic load will be evaluated, since port of Klaipeda must accept sewage from all passenger ships willing to discharge sewage.

Ro-Pax ferries currently operating routes in port of Klaipeda are equipped with sufficient sewage treatment facilities and the operator is not planning to discharge sewage in port of Klaipeda, therefore sewage from ferries will not be calculated assessing adequacy of sewage reception facilities in port of Klaipeda.

Increase in volumes of sewage accepted is likely to come from cruise ships during cruise season (May to October). During the period of 2011-2013, on average, 45 cruise ships per year visited port of Klaipeda, however in 2014 number of ships increased to 62, therefore further forecast will be calculated assuming that average of 60 cruise ships is expected per year.

Cruise ships are served at Central Klaipeda terminal and at Cruise and naval vessel quay, which both can serve up to two cruise ships per visit (depending on size of cruise ship). Analysis of cruise ship 
schedules revealed that is very unlikely to have four cruise ships visiting port of Klaipeda on the same day; therefore scenario when three ships will be served at the same time will be assessed. Normally, up to two ships are visiting the port on the same day (8 cases in cruise season 2014), however in 2015 three ship are expected on the same day (once). Forecast will be carried out assuming that until year 2020; approximately 60 cruise ships will visit port of Klaipeda every year, with cases of three cruise ships visiting port on the same day.

Volumes of sewage from cruise ships are calculated according to previously stated assumptions, statistic data on port of Klaipeda and HELOM guidelines. Statistic data for the period of 2011-2013 reveals that cruise ships visiting port of Klaipeda had an approximate average of 700 passengers. On average, number of crew members on cruise ships is 0,5 of crew member per passenger, meaning that cruise ship carrying 700 passengers is likely to have $350 \mathrm{crew}$ members. Volumes of sewage per person are calculated using HELCOM Guidelines for capacity calculation of sewage system on board passenger ship, which suggest that one person on-board generates 70 litres of black sewage and 230 litres of grey sewage per voyage lasting 2 hours. Black and grey sewage is accepted using same reception facilities in port of Klaipeda, therefore it will be considered that volumes of sewage per person in cruise ships are 300 litres $(70+230)$. Based on Due to geographical location of port of Klaipeda, voyages cruise ships take usually last for less than 24 hours, therefore approximate average volume of sewage per cruise ship normally visiting port of Klaipeda is $315 \mathrm{~m}^{3}$.

Based on previous assumption that at least 60 cruise ships will visit port of Klaipeda per season every year until year 2020. Based on previous calculation, cruise ships normally visiting port of Klaipeda, would carry approximately $315 \mathrm{~m}^{3}$ of sewage per visit, port of Klaipeda would have to accept up to 19 th. $\mathrm{m}^{3}$ of sewage per cruise season after amendments to Annex IV come into force.

Note, that this is maximum expected volumes in case if every visiting cruise ship would discharge sewage in port of Klaipeda. Despite the fact that some cruise ships are equipped with on-board sewage treatment facilities, to ensure adequacy port of Klaipeda should be capable of accepting maximum likely volumes from ships normally using the port. Until 2014, port of Klaipeda on average accepted $300 \mathrm{~m}^{3}$ of sewage per year, after amendments to Annex IV come into force, the port might have to handle 19 th. $\mathrm{m}^{3}$ of sewage from cruise ships per year.

\section{Technical requirements for sewage reception facilities}

Annex IV of MARPOL 73/78 convention provides standard dimensions of flanges for discharge connections. These requirements are provided in the table 4. MARPOL 73/78 does not provide any requirements for the SRF or their pumping capacities, maximum handled volumes of sewage, etc. The convention implies that SRF technical specifications should be sufficient to meet the needs of the ships normally using them; hence capacities of SRF depend on specific needs of individual port.

There are no legal concrete requirements for sewage reception facilities (amount, capacities, type), however, in 2013, HELCOM released guidelines "HELCOM interim guidance on technical and operational aspects of delivery of sewage by passenger ships to port reception facilities", where recommendations for ensuring adequate port receptions facilities are consolidated. Recommendations are based on stakeholder (cruise ship and ferry industries) proposals. These proposals (Table 5) are only recommendations, which are not mandatory to implement.

Table 5. Standard dimensions of flanges for discharge connections by MARPOL 73/78 Annex IV requirements

\begin{tabular}{|l|l|}
\hline Description & \multicolumn{1}{|c|}{ Dimension } \\
\hline Outside diameter & $210 \mathrm{~mm}$ \\
\hline Inner diameter & According to pipe outside diameter \\
\hline Bolt circle diameter & $170 \mathrm{~mm}$ \\
\hline Flange & $\begin{array}{l}\text { The flange is designed to accept pipes up to a maximum internal diameter of } 100 \mathrm{~mm} \text { and shall be } \\
\text { of steel or other equivalent material having a flat face. This flange, together with a suitable gasket, } \\
\text { shall be suitable for a service pressure of } 6 \mathrm{~kg} / \mathrm{cm}^{2}\end{array}$ \\
\hline Slots in flange & $\begin{array}{l}4 \text { holes } 18 \mathrm{~mm} \text { in diameter equidistantly placed on a bolt circle of the above } \\
\text { diameter, slotted to the flange periphery. The slot width to be } 18 \mathrm{~mm}\end{array}$ \\
\hline Flange thickness & $16 \mathrm{~mm}$ \\
\hline $\begin{array}{l}\text { Bolts and nuts: } \\
\text { quantity and diameter }\end{array}$ & 4, each of $16 \mathrm{~mm}$ in diameter and of suitable length \\
\hline
\end{tabular}


Table 6. Proposals of cruise ship and ferry operators regarding technical specifications of sewage reception facilities

\begin{tabular}{|l|l|}
\hline \multicolumn{1}{|c|}{ Adequacy according to the cruising industry } & \multicolumn{1}{|c|}{ Adequacy according to the ferry industry } \\
\hline - Direct shore-side connections with discharge capacity of $200-300 \mathrm{~m}^{3} \mathrm{per}$ \\
hour, and port capacity to receive $800-1200 \mathrm{~m}^{3}$ per cruise ship, to cater for \\
the needs of the larger cruise vessels;
\end{tabular} $\begin{aligned} & \text { Direct shore-side PRF connections } \square \text { port } \\
& \text { receiving capacity of } 200 \mathrm{~m}^{3} / \mathrm{h} ; \\
& \text { - possibility to discharge up to } 270 \mathrm{~m}^{3} \text { of sewage sludge and bio-residuals } \\
& \text { per ship; }\end{aligned} \begin{aligned} & \text { berths; } \\
& \text { - non-availability clause when PRFs are not } \\
& \text { that reception facilities are available at all time and at all berths and not } \\
& \begin{array}{l}\text { cause inconvenience or have health implications for passengers; } \\
\text { back-up plans are in place for situations when the reception facilities are } \\
\text { offline/inadequate. }\end{array}\end{aligned}$

Sewage reception in port of Klaipeda is carried out by subcontractor. This practice is very common in EU ports. In case of port of Klaipeda, contract is signed every three years with a company that wins public tender. Tenders specify capacities and capabilities for sewage reception facilities. Sewage is accepted using tankers (Table 7) or trucks, depending on what amount of sewage needs to be accepted. Trucks are subcontracted if necessary. The company possesses all discharge connections specified in MARPOL 73/78 Annex IV, as well as other connections and pump.

Table 7. Sewage reception facilities in port of Klaipeda

\begin{tabular}{|c|c|c|}
\hline Tankers & Sewage tank capacities & Sewage reception capacities $\mathbf{2 5 0} \mathbf{~ m}^{3} / \mathbf{h}$ \\
\hline „Dane““ & approximately $1200 \mathrm{~m}^{3}$ & approximately $250 \mathrm{~m}^{3} / \mathrm{h}$ \\
\hline „Banga“ & approximately $300 \mathrm{~m}^{3}$ & approximately $200 \mathrm{~m}^{3} / \mathrm{h}$ \\
\hline
\end{tabular}

Accepted sewage is discharged from tankers to trucks and delivered to municipal sewage treatment facilities of Klaipeda. Sewage reception facilities are limited by sewage discharge capacities from tankers to trucks: delivery of $200 \mathrm{~m}^{3}$ of sewage takes 3-4 hours), therefore for further calculation assumption will be made that tankers are able to accept sewage once per day, during the hours when passengers ships are anchored in port.

\section{Adequacy assessment of sewage reception facilities in port of Klaipeda}

\subsection{General assessment}

2011 resolution MEPC.200(62) regarding amendments to MARPOL 73/78 Annex IV, states that port reception facilities should be adequate to needs of ships normally using the port to ensure that sewage is accepted without undue delay to ships. MARPOL 73/78 does not specify what port reception facilities are considered adequate.

Guidelines for Ensuring the Adequacy of Port Reception Facilities (Resolution MEPC.83(44) from 2000), is intended to assist States in planning and providing adequate port waste reception facilities and encourage States to develop environmentally appropriate methods of disposing of ships' wastes ashore. Relevant for EU members of the Baltic Sea, adequacy is also regulated by Directive 2000/59/EC. Article 4 of this Directive is dedicated to the availability of PRF adequate to meet the needs of the ships normally using the port without causing undue delay to ships.

In the Guideline for Ensuring the Adequacy of Port Reception Facilities, adequate facilities can be defined as those which:

- mariners use;

- fully meet the needs of the ships regularly using them;

- do not provide mariners with a disincentive to use them; and

- Contribute to the improvement of the marine environment.

The facilities provided by the port should:

- meet the needs of the ships normally using the port; and

- allow for the ultimate disposal of ships' wastes to take place in an environmentally appropriate way.

Adequacy assessment will be carried out based on adequacy criteria identified. Each identified criteria were assessed. Criteria and their assessment are defined in Table 8. 
Sewage reception facilities shall be considered adequate if they meet all the criteria for adequacy. After the assessment of adequacy was carried out, conclusion was reached that sewage reception facilities in port of Klaipeda are adequate to needs of ships normally using the port.

Table 8. Criteria for adequacy assessment of sewage reception facilities in port of Klaipeda

\begin{tabular}{|c|c|}
\hline Adequacy assessment criteria & Definition \\
\hline $\begin{array}{l}\text { Sewage reception facilities meet the needs of the } \\
\text { ships normally using the port }\end{array}$ & \multirow{2}{*}{$\begin{array}{l}\text { These two criteria will be evaluated as a combination, as sewage reception } \\
\text { facilities must meet both to be considered adequate. Further information was } \\
\text { gathered for assessment: } \\
\text { - } \quad \text { profile of ships normally using port of Klaipeda; } \\
\text { - needs of ships normally using port of Klaipeda; } \\
\text { Assessment whether sewage reception facilities in port of Klaipeda meet } \\
\text { needs of ships normally using the port. Adequacy was assessed defining the } \\
\text { most likely scenario of maximum load and maximum expected volumes of } \\
\text { sewage in port of Klaipeda based on profile of ships normally using the port. }\end{array}$} \\
\hline $\begin{array}{l}\text { Sewage reception facilities do not cause undue } \\
\text { delay to ships }\end{array}$ & \\
\hline $\begin{array}{l}\text { Sewage reception facilities fully meet the needs of } \\
\text { the ships regularly using them }\end{array}$ & \multirow{2}{*}{$\begin{array}{l}\text { Resolution IMO MEPC.83(44) Guidelines for ensuring the adequacy of port } \\
\text { waste reception facilities provide sample questionnaire to assess accessibility } \\
\text { of sewage reception facilities. This questionnaire was used to assess these } \\
\text { two criteria. }\end{array}$} \\
\hline Sewage reception facilities are accessible to ships & \\
\hline
\end{tabular}

\subsection{Adequacy assessment of sewage reception facilities in port of Klaipeda for needs of ships normally using the port}

According to the EU directive 2000/59/EC and the IMO in 2010 resolution MEPC.83 (44) Guidelines for Ensuring adequacy of port reception facilities adequacy is if waste reception facilities match needs of ships normally using the port needs. Further assessment was carried out assuming that sewage reception facilities in port of Klaipeda must be adequate to meet needs of cruise ships using the port, as ferries using the port are not using and not planning to use sewage reception facilities after MARPOL 73/78 Annex IV amendments come into force (see chapter 1.4.3 for more information).

Needs of cruise ships normally using the port. Analysis of ships normally using port of Klaipeda concluded that cruise ships visiting port of Klaipeda carry approximate average of 700 passengers and 350 crew member per ship. Forecasted volumes of sewage to be discharged in port of Klaipeda due to amendments to Annex IV concluded that such cruise ship is likely to carry $315 \mathrm{~m}^{3}$ of sewage to be discharged in port of Klaipeda.

Larger ships than normal using port of Klaipeda. HELCOM guidelines provide proposals from cruise ship operators that port serving cruise ships should be able to accept $800-1200 \mathrm{~m}^{3}$ of sewage per visit of cruise ship with pumping capacity of $200 \mathrm{~m}^{3} / \mathrm{h}$. port of Klaipeda serves cruise ships that would produce such volumes of sewage per their voyage. These ships are not frequent visitors, however port of Klaipeda must be prepared to accept large volumes of sewage, therefore adequacy will be assessed for ships larger than normally using the port.

Sewage discharge capacities. Despite the fact that industry requested pumping capacities are 200 $\mathrm{m}^{3} / \mathrm{h}$, the most of the ships are capable of pumping sewage with capacity not exceeding $100 \mathrm{~m}^{3} / \mathrm{h}$. Further assessment will be carried out assuming that average cruise ship normally using the port is capable of discharging sewage at rate of $100 \mathrm{~m}^{3} / \mathrm{h}$, and larger that normally cruise ship is capable of discharging sewage at rate of $200 \mathrm{~m}^{3} / \mathrm{h}$.

Load scenarios in port of Klaipeda. Approximately, at least 60 cruise ships are expected to visit port of Klaipeda until 2020 every year during the cruise season. The port is likely to serve maximum of three ships per day. Adequacy assessment scenarios will be composed from combinations of ships normally using the port and larger than normal ships.

Duration of ship visits in port of Klaipeda. Analysis of ships normally using port of Klaipeda concluded that 98 per cent of ships visiting the port stay for at least 6 hours, 75 per cent stay for at least 8 hours. HELCOM interim guidance on technical and operational aspects of delivery of sewage by passenger ships to port reception facilities states that cruise ships stay at ports they are visiting for 8-11 hours. Based on analysis conclusions and recommendation, it is assumed that cruise ships are staying 8 hours at the port, therefore sewage must be accepted during the stay. 


\subsection{Adequacy assessment when 1 ship is served}

Scenario, when 1 normal cruise ship is served. If port of Klaipeda is visited by an average cruise ship, carrying $315 \mathrm{~m}^{3}$ of sewage, it would be accepted in three hours. Depending on ships pumping capacities, $1200 \mathrm{~m}^{3}$ of sewage could be accepted. Considering previous assumptions that cruise ships stay in the port for 8 hours, and pumping capacities of sewage reception facilities in port of Klaipeda are $200 \mathrm{~m}^{3} / \mathrm{h}$, maximum volume of sewage to be accepted is $1500 \mathrm{~m}^{3}$, sewage reception facilities in port of Klaipeda are adequate for this scenario.

Scenario, when 1 larger than normal cruise ship is served. If port of Klaipeda is visited by larger than normally cruise ship carrying $1200 \mathrm{~m}^{3}$ of sewage, sewage would be accepted in 6 hours. Considering previous assumptions that cruise ships stay in the port for 8 hours, and pumping capacities of sewage reception facilities in port of Klaipeda are $200 \mathrm{~m}^{3} / \mathrm{h}$, maximum volume of sewage to be accepted is $1500 \mathrm{~m}^{3}$, sewage reception facilities in port of Klaipeda are adequate for this scenario.

\subsection{Adequacy assessment when 2 ships are served}

Scenario, when 2 normal cruise ships are served. If port of Klaipeda is visited by two average-sized cruise ships each carrying approximately $315 \mathrm{~m}^{3}$ of sewage, sewage would be accepted in three hours serving both ships at the same time using both tankers sewage reception subcontractor owns. Model when sewage is accepted from one ship and other ship is served afterwards is also possible; sewage would be accepted in 6 hours. Considering previous assumptions that cruise ships stay in the port for 8 hours, and pumping capacities of sewage reception facilities in port of Klaipeda are $200 \mathrm{~m}^{3} / \mathrm{h}$, maximum volume of sewage to be accepted is $1500 \mathrm{~m}^{3}$, sewage reception facilities in port of Klaipeda are adequate for this scenario.

Scenario when 1 normal and 1 larger than normal cruise ship is served. If port of Klaipeda is visited by one average-sized cruise ship carrying approximately $315 \mathrm{~m}^{3}$ of sewage, and one larger than normal cruise ship carrying approximately $1200 \mathrm{~m}^{3}$ of sewage, sewage would be accepted using smaller tanker in 3 hours and using the larger tanker in 6 hours. Savage would be accepted at the same time from both ships using two tankers. Considering previous assumptions that cruise ships stay in the port for 8 hours, and pumping capacities of sewage reception facilities in port of Klaipeda are $200 \mathrm{~m}^{3} / \mathrm{h}$, maximum volume of sewage to be accepted is $1500 \mathrm{~m}^{3}$, sewage reception facilities in port of Klaipeda are adequate for this scenario.

Scenario when 2 larger than normal cruise ships are served (unlikely scenario). This scenario is unlikely, since large cruise ships are often equipped with sufficient on-board sewage treatment facilities for long voyages, however this scenario will be assessed as well to assess whether sewage reception facilities are sufficient to deal with largest likely volumes of sewage. If port of Klaipeda is visited by to larger than normally cruise ships each carrying approximately $1200 \mathrm{~m}^{3}$ of sewage, still only $1500 \mathrm{~m}^{3}$ of sewage would be accepted in 8 hours meaning that ships would not fully unload, only discharging approximately $750 \mathrm{~m}^{3}$ of sewage. This amount is sufficient for cruise ship to safely reach other seaports in the Baltic Sea, therefore sewage reception facilities in port of Klaipeda are adequate for this scenario.

\subsection{Adequacy assessment when 3 ships are served}

Scenario, when 3 normal cruise ships are served. If port of Klaipeda is visited by three averagesized cruise ships each carrying approximately $315 \mathrm{~m}^{3}$ of sewage, sewage would be accepted from two ships simultaneously in three hours using two tankers and from third ship afterwards in three more hours, taking total six hours to accept sewage from all three cruise ships. Considering previous assumptions that cruise ships stay in the port for 8 hours, and pumping capacities of sewage reception facilities in port of Klaipeda are $200 \mathrm{~m}^{3} / \mathrm{h}$, maximum volume of sewage to be accepted is $1500 \mathrm{~m}^{3}$, sewage reception facilities in port of Klaipeda are adequate for this scenario.

Scenario when 2 normal cruise ships and 1 larger than normal cruise ship are served. If port of Klaipeda is visited by two average-sized cruise ships each carrying approximately $315 \mathrm{~m}^{3}$ of sewage, sewage would be accepted in three hours serving both ships at the same time using two tankers. Afterwards, the third cruise ship would be served accepting up to $900 \mathrm{~m}^{3}$ of sewage in approximately 4-5 hours while ship is staying at the port. If larger than normal ship would have more than $900 \mathrm{~m}^{3}$ of sewage, some sewage would not be accepted, however sufficient amount of sewage would be accepted for the ship to safely reach other ports in The Baltic Sea. Sewage reception facilities in port of Klaipeda are adequate for this scenario. 


\section{Adequacy assessment by other criteria}

Sewage reception facilities fully meet the needs of the ships regularly using them and sewage reception facilities are accessible to ships. Port of Klaipeda did not receive any complaints regarding inadequacy of sewage reception facilities. Facilities were used by mariners and since 2005 each year 300 $\mathrm{m}^{3}$ of sewage was discharged in port of Klaipeda, therefore facilities are considered as used. IMO MEPC.83(44) resolution Guidelines for ensuring the adequacy of port waste reception facilities provide sample questionnaire to assess accessibility of sewage reception facilities (Table 9). If port of Klaipeda meets requirements provided in the questionnaire, sewage reception facilities should be considered adequate by this criterion.

Table 9. Assessment of sewage reception facilities in port of Klaipeda according to IMO MEPC.83(44) Guidelines for ensuring the adequacy of port waste reception facilities

\begin{tabular}{|c|c|}
\hline Question & Justification \\
\hline $\begin{array}{l}\text { Where is the sewage disposed of: } \\
\text { directly to reticulated sewage } \\
\text { system; } \\
\text { directly to mobile facility; } \\
\text { - } \quad \text { ships to holding tanks then pumped } \\
\text { to a mobile facility; } \\
\text { ships to on-site treatment facility to } \\
\text { sewerage system; } \\
\text { other. }\end{array}$ & $\begin{array}{l}\text { Currently, sewage is accepted from passenger ships to tankers and then pumped to } \\
\text { trucks. During the period of 2007-2014, average of } 300 \mathrm{~m}^{3} \text { of sewage was accepted } \\
\text { each year from cruise ships. HELCOM Roadmap for upgrading the availability of } \\
\text { port reception facilities for sewage in major passenger ports states that if ports } \\
\text { mostly serve passenger ferries, tankers and trucks are considered adequate sewage } \\
\text { reception facilities. } 2013 \mathrm{~m} \text {. HELCOM minister declaration HELCOM interim } \\
\text { guidance on technical and operational aspects of delivery of sewage by passenger } \\
\text { ships to port reception facilities also states that tankers and trucks could be } \\
\text { considered adequate sewage reception facilities in those cases when fixed facilities } \\
\text { are not feasible or there are technical issues with implementation. }\end{array}$ \\
\hline $\begin{array}{l}\text { Are there any restrictions on receipt or } \\
\text { collection of sewage wastes by service } \\
\text { providers? } \\
\text { - minimum quantity; } \\
\text { - } \quad \text { maximum quantity; } \\
\text { - } \quad \text { discharge rate } \mathrm{m}^{3} / \mathrm{h} ; \\
\text { - } \quad \text { vessel type; } \\
\text { vehicle access to berth. }\end{array}$ & $\begin{array}{l}\text { Sewage pumping capacities are limited by passenger ship pumping capacities: } \\
\text { sewage reception facilities in port of Klaipeda are capable of pumping sewage } 200 \\
\mathrm{~m}^{3} / \mathrm{h} \text {. Volumes of sewage discharged in port of Klaipeda are not sufficient to } \\
\text { identify significant trends, therefore statistic data from port of Helsinki will be used } \\
\text { as a case study: in } 2012 \text {, largest pumping capacity passenger ship visiting the port } \\
\text { had was } 120 \mathrm{~m}^{3} / \mathrm{h} \text {. There are no other restrictions to sewage reception, therefore } \\
\text { sewage reception facilities in port of Klaipeda are considered adequate. }\end{array}$ \\
\hline $\begin{array}{l}\text { Are sewage reception facilities available: } \\
\text { - } \quad 24 \text { h a day } 7 \text { days per week; } \\
\text { - } \quad 24 \text { h a day, } 5 \text { days per week; } \\
\text { - } \quad \text { Business hours, } 7 \text { days per week; } \\
\text { - } \quad \text { Business hours, } 5 \text { days per week. }\end{array}$ & $\begin{array}{l}\text { Sewage is accepted when requested by visiting ships, no availability limitations are } \\
\text { set, and therefore sewage reception facilities in port of Klaipeda are considered } \\
\text { adequate. }\end{array}$ \\
\hline $\begin{array}{l}\text { Is prior notice for receipt of sewage } \\
\text { required: } \\
\text { - } \quad 0 \text { hours; } \\
\text { - } \quad 12 \text { hours; } \\
\text { - } \quad 24 \text { hours; } \\
\text { - } \quad 48 \text { hours. }\end{array}$ & $\begin{array}{l}\text { Notice is requested to be sent } 24 \text { hours prior visit if voyage is to last longer than } 24 \\
\text { hours (as stated in EU directive 2000/59/EC). Port of Klaipeda serves ferries and } \\
\text { cruise ships operating o strict schedules, therefore providing prior notice is easy to } \\
\text { plan and send, port of Klaipeda is aware of incoming ships as well, therefore } \\
\text { sewage reception facilities in port of Klaipeda are considered adequate. }\end{array}$ \\
\hline $\begin{array}{l}\text { Is the waste reception service available: } \\
\text { - at no cost; } \\
\text { at a cost incorporated into standing } \\
\text { port use charge; } \\
\text { at a cost charged in addition to } \\
\text { other services. }\end{array}$ & $\begin{array}{l}\text { Based on HELCOM recommendations, non-special fee is applied to all ships } \\
\text { visiting port of Klaipeda, which includes fee for reception of sewage as well. Fee is } \\
\text { charged regardless of whether sewage was discharged or not. Same fee model is } \\
\text { suggested by EU, therefore sewage reception facilities in port of Klaipeda are } \\
\text { considered adequate. }\end{array}$ \\
\hline $\begin{array}{l}\text { Is a waste collection service available: } \\
\text { - } \quad \text { at all berths; } \\
\text { - } \quad \text { at most berths; } \\
\text { - } \quad \text { at only one berth; } \\
\text { - } \quad \text { vessels anchored within the port; } \\
\text { - } \quad \text { vessels anchored outside the port. }\end{array}$ & $\begin{array}{l}\text { Waste collection services are available to all ships visiting port of Klaipeda in spite } \\
\text { at which berth they are served. Considering the fact that this study analyses } \\
\text { passenger ships which do not anchor outside limits of the port, sewage reception } \\
\text { facilities in port of Klaipeda are considered adequate. }\end{array}$ \\
\hline
\end{tabular}

Current technical model for reception of sewage is to discharge sewage from passenger ships to tankers and then from tankers to trucks, which deliver sewage to municipal sewage treatment facilities, where it is treated to meet requirements of legal framework, therefore sewage is accepted in a way that is environmentally appropriate in port of Klaipeda and sewage reception facilities are considered adequate.

Considering proposals from ferry and cruise ship industries provided in HELCOM guidelines, ports serving these types of vessels should be equipped with fixed sewage reception facilities. If passenger number in port of Klaipeda is expected to grow, installing fixed sewage reception facilities 
should be considered in berths which serve cruise ships (priority) and berths where ferries are served. Fixed reception facilities should have direct connection to municipal sewage system.

If port of Klaipeda will continue serving the most of passengers from ferries running on fixed schedules and number of passengers from cruise ships will not exceed 100 th., tankers and trucks would suffice needs for reception of sewage in port of Klaipeda.

\section{Conclusions}

The assessment of adequacy according IV Annex of MARPOL is relative to requirements and needs of Ro-Pax ferry lines and cruise ships operators. Adequacy in this case in general is measured by demand/capacities ratio and technical solution adequacy to the needs of each operator. The methodology which was applied to justify adequacy of port of Klaipeda to the requirements defined in IV Annex of MARPOL confirms adequacy of the port at the time when the assessment was conducted. Such approach may be used in other ports also.

However the issue is related to relativeness of assessment results. If the volumes of sewages and capacities of facilities are predictable for years ahead by the method applied by authors, however the technical solution adequacy (fixed facility, tanker or truck) is unpredictable. Klaipeda port as well as many other ports in Baltic is still using the tankers of truck for reception of sewages because in still high level of investments needed for fixed facilities such as underground pipelines. Until the ship operators commonly agree on using tankers or trucks for sewages it is in respect of MARPOL annex IV. However if at least one claim comes from operators it will be perceived as inadequacy to the needs.

\section{References}

1. HELCOM recommendation 11/10 Guidelines for capacity calculation of sewage system on board passenger ships (1990) Baltic Marine Environment Protection Commission.

2. HELCOM overview on port reception facilities for sewage in the Baltic Sea area and related trends in passenger traffic (2013) Baltic Marine Environment Protection Commission.

3. Annex IV of MARPOL $73 / 78$ convention. HELCOM: Interim guidance on technical and operational aspects of delivery of sewage by passenger ships to port reception facilities (2013) Baltic Marine Environment Protection Commission.

4. Chin-Shan, Lu; Wen-Hong, Liu; Wooldridge Ch. (2014) Maritime environmental governance and green shipping. Maritime Policy \& Management 41(2): 131-133.

5. Demand study port infrastructure (2013) Project CLEANSHIP report. (Clean Baltic Sea Shipping, funded by Baltic Sea Programme 2007-2013).

6. Everett, S.; Pettitt, T. (2006) Effective corporatization of ports is a function of effective legislation: legal issues in the existing paradigm. Maritime Policy \& Management 33(3): 219-232.

7. Homsombat, W.; Yip, T.L.; Yang, H.; Fu, X. (2013) Regional cooperation and management of port pollution. Maritime Policy \& Management 40(5): 451-466.

8. Julian, M. (2000) MARPOL 73/78: the International Convention for the Prevention of Pollution from Ships. Maritime Studies 2000(113): 16-23.

9. Klopott, M. (2013) Restructuring of environmental management in Baltic ports: case of Poland. Maritime Policy \& Management 40(5): 439-450.

10. Luo, M.; Yip, T.L. (2013) Ports and the environment. Maritime Policy \& Management 40(5): 401-403.

11. Mattson, G. (2006) MARPOL 73/78 and Annex I: An Assessment of its Effectiveness. Journal of International Wildlife Law \& Policy 9(2): 175-194.

12. Moon, D.S.-H.; Woo, J.K. (2014) The impact of port operations on efficient ship operation from both economic and environmental perspectives. Maritime Policy \& Management 41(5): 444-461.

13. Panasiuk, I.; Lebedevas, S. (2014) The assessment of the possibilities for the Lithuanian fleet to comply with new environmental requirements. Transport 29(1): 50-58.

14. Project CLEANSHIP (Clean Baltic Sea Shipping) report DEMAND STUDY PORT INFRASTRUCTURE, funded under Baltic Sea Programme 2007-2013.

15. Venus Lun, Y.H.; Lai K-H.; Christina W.Y.; Cheng T.C.E. (2014) Green shipping practices and firm performance. Journal: Maritime Policy \& Management 41(2): 134-148.

16. Zondag, B.; Bucci, P.; Gützkow, P.; de Jong, G. (2010) Port competition modelling including maritime, port, and hinterland characteristics. Maritime Policy \& Management 37(3): 179-194. 